Western University

Scholarship@Western

History Publications

History Department

4-2019

Sympathetic Physics: The Keely Motor and the Laws of Thermodynamics in Nineteenth-Century Culture

Robert MacDougall

The University of Western Ontario, rmacdou@uwo.ca

Follow this and additional works at: https://ir.lib.uwo.ca/historypub

Part of the American Studies Commons, Cultural History Commons, $\underline{\text { History of Science, }}$ Technology, and Medicine Commons, Other Physics Commons, and the United States History Commons

Citation of this paper:

MacDougall, Robert, "Sympathetic Physics: The Keely Motor and the Laws of Thermodynamics in Nineteenth-Century Culture" (2019). History Publications. 391.

https://ir.lib.uwo.ca/historypub/391 


\title{
Sympathetic Physics: The Keely Motor and the Laws of Thermodynamics in Nineteenth-Century Culture
}

\author{
Robert MacDougall
}

Department of History

University of Western Ontario

London, Ontario, Canada

www.robmacdougall.org

rmacdou@,uwo.ca

As published in Technology and Culture, Volume 60, Number 2 (April 2019).

Final Pre-Publication Draft [Published page numbers appear in brackets below.]

Cite as: Robert MacDougall, "Sympathetic Physics: The Keely Motor and the Laws of Thermodynamics in Nineteenth-Century Culture," Technology and Culture 60:2 (April 2019), pp. 438466.

[p. 438:] Abstract: In Philadelphia in the 1870s, John Worrell Keely announced the invention of a fantastic new motor that could, he promised, drive locomotives, power factories, and even defy gravity without fuel or heat. The Keely Motor became the most notorious perpetual motion scheme of the nineteenth century, attracting believers and investors for nearly thirty years. This article explores the "work" the motor performed for Keely, his supporters, and his critics-not physical work, but financial, cultural, and psychological. To investors, the Keely Motor represented a dream of riches without effort. To Keely's critics, the motor offered an opportunity to defend the legitimacy of the new industrial economy. And to Keely's staunchest supporters, including the author and heiress Clara Moore, the motor was a rebuke to the laws of thermodynamics and the parsimonious political economy, the pessimistic theology, and the anti-feminist psychiatry those laws were alleged to support.

Bio and Acknowledgments: Robert MacDougall is associate professor of history at the University of Western Ontario, and author of The People's Network: The Political Economy of the Telephone in the Gilded Age (2014). He is writing a book about the Keely Motor and other nineteenth-century perpetual motion devices. This research is supported by the Social Science and Humanities Research Council of Canada. For input and inspiration on this article, he thanks the graduate students in his Writing History seminar, along with several colleagues, $T \& \mathrm{C}$ s anonymous reviewers, and associate editor Barbara Hahn. 
In Philadelphia, in 1873, a tradesman and tinkerer named John Worrell Keely announced that he had invented, or was just about to invent, a fantastic new motor unlike any the world had ever seen. When completed, Keely promised, his motor would drive locomotives without heat or smoke, power factories without coal, and propel ships across the Atlantic using only a teacup of water for fuel. Keely spent the next twenty-five years on the verge of perfecting this marvelous machine. Hundreds witnessed demonstrations of his prototypes, and thousands more came to believe there must be something to his claims. At least three Keely Motor [p. 439:] Companies were formed; the parent company attracted hundreds of thousands of dollars in investment (some say millions) and gained national renown. By the end of his life, Keely claimed to have split the atom and promised to defy gravity. Some said the Keely Motor would bring about world peace and cure all known disease.

It is a shame it never worked.

Historians of technology like Kenneth Lipartito, Graeme Gooday, and Henry Petroski have all explored the slippery history of failed technologies. In a well-known article on "The Social Meaning of Failure," Lipartito urges us to see success and failure as unstable categories. "Failures are not inherent in hardware," he writes, "but constructed by contingent social conditions."1

Technology, in other words, is rarely judged in purely functional terms; to describe a given device as a "success" or "failure" almost always involves cultural, political, and economic considerations. A machine might work in every technical sense yet still fail to attract buyers or believers. ${ }^{2}$ But how

\footnotetext{
${ }^{1}$ Kenneth Lipartito, "Picturephone and the Information Age," 52; Graeme Gooday, "Re-Writing the "Book of Blots"'; Henry Petroski, To Engineer is Human: The Role of Failure in Successful Design; Henry Petroski, To Forgive Design: Understanding Failure.

${ }^{2}$ Specifically, Lipartito was writing about Picturephone, a video telephone system developed by the American Telephone and Telegraph Company in the 1960s. When Lipartito's article was published in 2003, video telephony was a good example of a technology that had been technically viable for
} 
should we reckon with a machine that never worked — that could not have worked, according to the laws of physics as we understand them - yet nevertheless raised hundreds of thousands of dollars, captured public attention for decades, and still has true believers to this day?

This article revisits the Keely Motor, the most notorious perpetual motion machine of the nineteenth century, and explores the work that motor performed for John Keely, his supporters, and his critics. This "work" was not physical work, but financial, cultural, and psychological. In particular, I examine three groups among Keely's interpreters and interlocutors; the Keely Motor served each group in a different way. To investors in the Keely Motor Company, the motor represented the promise of riches, the dream of getting in on the ground floor of the next big thing. To Keely's critics, especially the magazine Scientific American, Keely was an irritant but also a useful foil. He offered them the opportunity to defend the legitimacy of the new industrial economy by performing their indignation at his scheme. Finally, to a small group of true believers, the Keely Motor seemed proof of a deeper metaphysical revelation. First among this number was the wealthy heiress and author Clara Jessup Bloomfield Moore. Moore has often been seen as Keely's victim or dupe; I argue that she was an important co-author of the Keely Motor phenomenon. She backed Keely financially but also reframed his motor in spiritual, philosophical, and even feminist terms. [p. 440:] She connected the motor to longstanding currents in American religion and made it the cornerstone of an alternative metaphysics—Moore called it "sympathetic vibratory physics" — that challenged the scientific and cultural orthodoxy of her day. ${ }^{3}$

decades, yet never caught on. The fact that video telephony did catch on in the years since 2003 only underscores the slipperiness of technological failure and success.

${ }^{3}$ Clara Bloomfield Moore, Keely and His Discoveries, xxv, and passim. 
The name of that orthodoxy was thermodynamics, the nineteenth century's new science of heat, energy, and work. The study of thermodynamics grew out of rumination about the efficiency of steam engines to become perhaps the most important development in nineteenth-century physics. The famous first and second laws of thermodynamics were developed in the first half of the century and codified as "laws" in the 1850s. ${ }^{4}$ The first law states that energy can never be created or destroyed. Thus, the total energy of a closed system remains constant. The second law states that energy can nevertheless be lost or dissipated, becoming unavailable for work. When, for example, the hot boiler and the cool condenser of a steam engine reach the same temperature, that engine can do no more work without the addition of energy from outside the system. In 1865, the German physicist Rudolf Clausius proposed the term "entropy" to describe this tendency towards dissipation, and rephrased the two laws of thermodynamics in cosmic terms: "The energy of the universe is constant," and "The entropy of the universe tends to a maximum."

The laws of thermodynamics do explain the impossibility of constructing a perpetual motion machine as that term is generally understood. But nineteenth-century scientists did not "discover" the laws of thermodynamics and thus "prove" perpetual motion impossible. If anything, the task of explaining why perpetual motion is impossible helped lead to the articulation of the famous laws. ${ }^{6}$

${ }^{4}$ William Thomson coined the term "thermo-dynamics" in 1854; the terms "First Law of Thermodynamics" and "Second Law of Thermodynamics" appeared in Macquorn Rankine's Manual of the Steam Engine and Other Prime Movers, published in 1859. Peter M. Harman, Energy, Force, and Matter, 45-71; Crosbie Smith, The Science of Energy, 1-14.

${ }^{5}$ Harman, Energy, Force, and Matter, 45-71.

${ }^{6}$ Charles Coulton Gillispie, The Edge of Objectivity, 366; Yehuda Elkana, The Discovery of the Conservation of Energy (Cambridge, Mass.: Harvard University Press, 1974), 28-32; Smith, The Science of Energy, 5051, 177. On the history of thermodynamics see also Thomas Kuhn, "Energy Conservation as an Example of Simultaneous Discovery"; Kenneth L. Caneva, Robert Mayer and the Conservation of Energy. The clearest short introduction is probably Gillispie, The Edge of Objectivity, 352-405. On the history 
And the prohibition against perpetual motion was hardly their most significant implication. As Clausius and others came to understand, the laws of thermodynamics were profound statements about the working and fate of the entire cosmos.

By the late nineteenth century, the laws of thermodynamics were widely publicized if not widely understood. Historians of science like Norton Wise, Crosbie Smith, and Greg Myers have shown that the new energy physics had [p. 441:] a remarkable impact on nineteenth-century culture, especially in Britain and the United States. ${ }^{7}$ The association of thermodynamics with the steam engine and industrialization gave the emerging science immense authority and prestige. The laws of thermodynamics, so satisfyingly authoritative and profound, were frequently invoked by scientists and non-scientists in discussions of political economy, theology, and culture. Tina Young Choi has traced the influence of thermodynamics on Victorian literature, while works by Janet Oppenheim and Sally Shuttleworth describe its perceived implications for medicine and education. ${ }^{8}$ By the 1870 s and 1880s, the new energy doctrines seemed to resonate into every corner of the culture, along with an associated language of pressure, dissipation, entropy, and waste.

Nineteenth-century discourse around thermodynamics, which at times bore little relation to actual science, lent the authority of science, in different contexts, to pessimistic forecasts about social decline, to parsimonious models of the economy, and to anti-feminist ideas in psychiatry and education. Yet thermodynamic discourse could be employed in different ways. Clara Moore's

of perpetual motion see Henry Dircks, Perpetuum Mobile; Arthur W.J.G. Ord-Hume, Perpetual Motion; Simon Schaffer, "The Show That Never Ends."

${ }^{7}$ M. Norton Wise, "Work and Waste: Political Economy and Natural Philosophy in Nineteenth Century Britain” (Parts I-III); Smith, The Science of Energy; Greg Myers, "Thermodynamics and the Rhetoric of Social Prophecy."

${ }^{8}$ Tina Young Choi, "Forms of Closure: The First Law of Thermodynamics and Victorian Narrative"; Janet Oppenheim, Shattered Nerves; Sally Shuttleworth, The Mind of the Child, 131-150. 
understanding of physics was idiosyncratic, to say the least, but she used the language of science to argue against the pessimistic, parsimonious, and anti-feminist ideas the laws of thermodynamics had been employed by others to support. The Keely Motor was, for Moore, both proof and symbol of a new physics — a more sympathetic physics, which married hard science to the realm of emotion and love. For Moore and those who followed in her footsteps, this was the real work of the Keely Motor. It helped them to counter the arguments of an unsympathetic establishment and imagine a different, better world.

\section{Vaporware}

There was nothing inside the motor; on this point, Keely was forthcoming from the start. It was the precise nature of that nothing that provoked dispute. At first, Keely said his motor ran on nothing but "cold vapor," a mysterious sort of unheated steam that he produced through "the disintegration of water."' Later, he and his supporters would claim he had captured the ether, that mysterious nothing once held to be everywhere and in all things. ${ }^{10}$ Others insisted, from the beginning, that Keely's motors contained nothing but compressed air. ${ }^{11}$

[p. 442:] John Worrell Keely was working as a varnisher in a furniture shop when he constructed what he then called his "Globe Motor."12 This first incarnation of the Keely Motor was

9 “The Keely Motor," New York Times, 11 June 1875, 1; “The Keely Motor Deception," Scientific American, 10 July 1875, 16; “Keely's Secret,” Los Angeles Times, 15 June 1890, 11.

10 “Keely's Etheric Vapor," New York Times, 22 September 1884, 5; Moore, Keely and His Discoveries, 11-29, 54-64. On ether, see Joe Milutis, Ether.

11 “Another New Motor," Scientific American, 2 May 1874, 273; "Pressure not a Motive Power," Scientific American, 30 May 1874, 226.

${ }^{12}$ The Keely Motor Criticized, a Republication in Pamphlet Form of a Series of Editorials Which Appeared in the Public Record of Philadelphia (Philadelphia: [n.p.], 1875), 2-5. By far the most thorough source on Keely's biography is Theo Paijmans, Free Energy Pioneer. 
a hollow metal sphere, about eight inches in diameter, that he could cause to spin rapidly upon a horizontal axis. Keely was not very clear on how the motor worked. He claimed at first to have produced a mysterious vapor through the mechanical agitation of air and water that was cheaper and more powerful than steam. But his explanations shifted from week to week, from talk of "disintegrators" and "vaporic force" to "globular transmission" and "the law of concordant assimilative harmony." "' Keely spoke in what the Chicago Tribune called "a Volapük intelligible only to Keely and the motor," an efflux of jargon which concealed his meaning "as effectively as the cuttlefish hides in his inky fluid." ${ }^{14}$ His writing was convoluted and hard to follow, yet in person he seems to have been marvelously persuasive. "Keely has one gift ... which is great enough to be called genius, and that is his skill in humbugging people," said the Atlanta Constitution. "He has great power by mere talk of setting aside all doubt." 15

Soon Keely's motor was the talk of the town. He left his old employer and moved into his own workshop, a former stable on North Twentieth Street. He built and rebuilt a series of motors, each one more elaborate and impressive than the last. The spinning spheres grew larger and so did their names: the "Globe Motor" became the "Dynasphere," then the "Hydraulic Motor," then the "Hydro-Vacuo Engine," and then the "Hydro-Pneumatic-Pulsating-Vacuo Engine."16 Newspapers started taking notice around 1874, first in Philadelphia, and soon around the country. "According to

13 “A Keely Séance," Scientific American, 29 June 1878, 401; “Keely’s Vaporic Force," New York Times, 21 September 1884, 8; Moore, Keely and His Discoveries, 178, 215-16.

14 “The Keely Motor Redivivus,” Chicago Tribune, 26 March 1888, 4. Volapük was a constructed language similar to Esperanto.

15 “Keely and His Motor," Atlanta Constitution, 28 September 1885, 1.

${ }^{16}$ Paijmans, Free Energy Pioneer, 15-22. 
the statements of this gentleman," the New York Times reported in 1875, "the newly-discovered power is inevitably destined to revolutionize the entire mechanical world."17

Philadelphia had seen attempts at perpetual motion before. Sixty years earlier, a man named Charles Redheffer constructed a device in which weights sliding down ramps seemed to propel a large rotating wheel. After several months of notoriety, Redheffer's deception was dramatically exposed by, among others, the steamboat inventor Robert Fulton. At one demonstration of the device, Fulton discovered a hidden cord of catgut running from the machine into the walls. He followed it up to a tiny attic, [p. 443:] or so the story goes, where a decrepit old man was concealed, turning a crank to power Redheffer's wheel. ${ }^{18}$

Fulton's involvement is interesting because the Keely Motor was in a way the descendant of both Redheffer and Fulton's inventions. Keely's motors did not look like what we might call "classical" perpetual motion machines. ${ }^{19}$ They were not obviously mechanical. There were no balls rolling down ramps or over-balanced wheels. Keely's creations were all valves and vapors, "pulsating diaphragms" and "vacuum chambers." 20 Newspapers struggled even to describe the Keely Motor. "The generator is a very peculiar-looking machine," said the Washington Post, "and can be compared to nothing which will give the public anything like an intelligent idea of its appearance."21 "It is wholly unlike any other collection of globes and tubes that has ever been exhibited," said the New

\footnotetext{
17 “The Keely Motor,” New York Times, 3 July 1875, 4.

${ }^{18}$ Cadwallader D. Colden, The Life of Robert Fulton, 216-220.

${ }^{19}$ Keely himself eschewed the term "perpetual motion"; see Moore, Keely and His Discoveries, 111.

${ }^{20}$ The quotes come from Keely's unsuccessful application for a patent, quoted in "Keely's Motor," Chicago Tribune, 11 August 1875, 3.

21 “Keely and His Motor," Washington Post, 29 April 1879, 2.
} 
York Herald, which hardly clarified things. ${ }^{22}$ Redheffer's hoax was an old one. The Keely Motor was something new: perpetual motion for the age of steam. <Fig. 1 (Hydro Vacuo Engine) about here $>$

From the 1830s on, a number of new inventions captured intellectual attention in both America and Europe: steam engines, voltaic batteries, sensitive atmospheric instruments, and cameras. John Tresch has described this era as the age of "romantic machines." Romantic machines, he argues, were not classical machines like levers, clocks, or cranks. They were more mysterious. Their workings were often concealed. They involved conversions and transmutations, and they contained their own motive forces within them. "The kinds of machines we use," Tresch writes, "are bound up with the ways we think about nature and the ways we know it." ${ }^{24}$ Classical machines seemed to belong to a clockwork universe, a world that was stable and deterministic, made up of discrete blocks of matter. Romantic machines, by contrast, implied a more organic, interdependent understanding of nature. They confounded distinctions between animate and inanimate objects and hinted at vast forces hidden within molecules of matter.

The steam engine in particular had profound implications. It was through contemplating high-pressure steam engines in the 1820s that the French engineer Sadi Carnot arrived at the theory that heat and motive power were ultimately one and the same. This would become the founding statement of thermodynamics, the idea that replaced a mechanical universe of discrete objects with one of continuous matter, alive with kinetic [p. 445:] and potential energy. A century later, Lawrence Henderson was thinking of Carnot and the birth of thermodynamics when he famously

\footnotetext{
${ }^{22}$ New York Herald quoted in "The Keely Motor Deception," Scientific American, 14 May 1881, 305.

${ }^{23}$ John Tresch, The Romantic Machine, 1-26.

${ }^{24}$ Tresch, The Romantic Machine, xi.
} 
remarked that "science owes more to the steam engine than the steam engine owes to science."25 But it was not only scientists who meditated on the meaning of steam. In France, Tresch observes, steam engines and other new machines became symbols of romanticism, republicanism, and social reform. To those most enthralled by them, steam engines were "devices of cosmic unity," symbols of the oneness of matter, energy, and spirit. ${ }^{26}$ The Keely Motor would offer its believers a similar symbol. It was proof, according to Clara Moore, "that the universal ether that permeates all molecules is the tangible link between God and man" and that "we are connected in sympathy with all other souls and with the objects of nature, even, to the stars and all the heavenly bodies." ${ }^{27}$

At first, however, Keely's motives seemed considerably less celestial. In 1874, he partnered with a Philadelphia patent lawyer named Charles B. Collier to create the Keely Motor Company and sell shares in his invention. ${ }^{28}$ Within eight months of its incorporation, the Keely Motor Company had secured more than one hundred investors, and claimed to have raised $\$ 4$ million in capital. Perhaps more believable reports said the company took in between $\$ 100,000$ and $\$ 500,000$ in its first year. (Even $\$ 100,000$ in 1875 would be equivalent to over $\$ 2$ million today.) ${ }^{29}$ The Keely Motor Company issued stock, elected a board of directors, and held annual shareholder meetings, each one

\footnotetext{
${ }^{25}$ Gillispie, The Edge of Objectivity, 357.

${ }^{26}$ Tresch, The Romantic Machine, 6-16, 27.

${ }^{27}$ Moore, Keely and His Discoveries, xxv, 16. Emphasis in original.

${ }^{28}$ There is some dispute about this date; I am trusting my earliest detailed source on Collier, his own letter to Scientific American. Charles B. Collier, “The Keely Motor," Scientific American, 17 July 1875, 36.

${ }^{29}$ Keely Motor Company, Annual Report (Philadelphia: G.V. Town \& Son, 1875); “The Keely Motor," New York Times, 11 June 1875, 1; “The Keely Motor," Chicago Tribune, 27 December 1875, 2; Charles S. Hill, "The History of the Keely Motor Company," Chicago Daily Tribune, 29 January 1899, 43.
} 
an opportunity to attract further press coverage and investment. ${ }^{30}$ Keely did not speak, yet, about the unity of the cosmos, only the profits certain to come to those with the foresight to invest in his dream. <Fig. 2 (Keely and Motor) about here>

Collier put a halt to Keely's public demonstrations of the motor, instead arranging a series of private displays for potential investors from Philadelphia and New York. At a typical demonstration, well-to-do men would be treated to a luncheon of sandwiches, oysters, and champagne. Keely would hold forth about vapors and vibratory forces while Collier translated into the language of stock options and dividends. After an extensive preamble, Keely would pour a quart or so of water into his machine, run the water through a series of chambers, and then turn a cock or spigot to unleash the force he claimed to have produced. A gauge would indicate some enormous amount of pressure, a heavy weight or a pair of [p. 446:] men sitting on a seesaw might be lifted towards the ceiling, and a wheel or ball would be made to spin at rapid speed. ${ }^{31}$ By 1879 , Keely added a "vaporic gun" or "vibratory cannon" to the proceedings, which fired a large bullet through several planks of wood. Around 1881, he began using tuning forks and fiddle bows in his demonstrations, explaining that his engine was "tuned" to certain musical vibrations. By 1884, he had largely dispensed with water and

30 “'The Keely Motor Heard From,” Chicago Tribune, 17 February 1879, 2; “Mr. Keely’s Invention,” Hartford Courant, 29 April 1879, 2.

${ }^{31}$ See for example "Keely Shows His Motor," New York Times, 19 October 1881, 5; "The Keely Motor Deception," Scientific American, 30 October 1875, 273; "Testing the Keely Motor," Hartford Daily Courant, 5 September 1877, 1; “The Keely Motor," Chicago Daily Tribune, 10 September 1877, 3; "Keely's Motor," Chicago Daily Tribune, 30 April 1879, 6; "Keely's Motor Moting," Boston Daily Globe, 5 November 1884, 3. 
vapor and appeared to activate his motor simply by playing a particular note with his tuning fork or bow. $^{32}$

Skeptics argued all along that Keely's devices did nothing that could not be explained by a hidden tank of compressed air. They asked why the motor could only be demonstrated in Keely's workshop, and only operated by Keely himself. At least one reporter pointed out a mysterious locked room on the ground floor of Keely's workshop, directly below where the motor sat on the floor above. And while Keely insisted his machines could [p. 447:] run for weeks if not indefinitely, they were never actually seen to run for more than a few minutes at a time. ${ }^{33}$

Still, investors kept coming. <Fig. 3 (KMC stock certificate) about here $>$ Shares in the Keely Motor Company rose in value from $\$ 50$ per share to $\$ 150$ by 1879 , ultimately peaking around \$300. According to Philadelphia's Public Record, at least 3,000 shares were purchased in New York at that price, and by 1881 all the company's original investors were able to get out of the scheme with a handsome profit. ${ }^{34}$ Keely himself lived well in these years. He had a pair of fine horses to draw his carriage around Philadelphia, and he took to wearing kid gloves, brightly-colored neckties, and diamond stickpins in his shirt. One lawyer's reckoning estimated that the Keely Motor Company paid Keely approximately $\$ 200,000$ in stock and cash over the years and advanced nearly as much to

\footnotetext{
32 “Keely Shows His Motor," New York Times, 19 October 1881, 5; “Another Keely Motor Exhibition," Scientific American, 5 November 1881, 293; “Keely’s Motor Moting,” Boston Daily Globe, 5 November 1884, 3.

33 “Mr. Keely and His Motor," New York Times, 29 March 1878, 5; “The Keely Motor," Chicago Daily Tribune 15 April 1878, 2; "Keely Shows His Motor," New York Times, 19 October 1881, 5.

34 “The Keely Motor Deception,” Scientific American, 29 January 1881, 69.
} 
his construction account. ${ }^{35}$ Scientific American observed drily in 1882: "There are fools in the world, no doubt; there may be some in the Keely Motor Company; but Mr. Keely is not one of them."’36

\section{[p. 448:] Something for Nothing}

The American press introduced Keely to a much larger audience than could troop up the stairs to his second-story workshop. Newspapers around the country indulged in breathless headlines about the Keely Motor and reprinted long press releases from Collier and other promoters. "The wildest dreams of the Arabian story-teller seem commonplace when compared with the marvels that are promised in this newly-discovered force of nature," declared the New York Times. ${ }^{37}$ Some coverage was skeptical, but most adopted a wait-and-see attitude. And even skeptical coverage spread Keely's fame. Keely's most relentless critic was the magazine Scientific American, which had a history of debunking perpetual motion devices well before the Keely Motor came on the scene. From the 1870s through the 1890s, Scientific American would write about Keely constantly—always critically, always attacking him as a swindler and a fraud. Yet in so doing, they gave him endless publicity. At the height of his fame, Scientific American was publishing something about Keely in almost every weekly issue. ${ }^{38}$

35 "Keely's Close Secret," Chicago Tribune, 29 July 1882, 10; “Keely, The Motor Man,” Chicago Tribune, 22 April 1888, 27; Charles S. Hill, "The History of the Keely Motor Company," Chicago Daily Tribune, 29 January $1899,43$.

36 “A Panic-Stricken Company,” Scientific American, 7 January 1882, 10.

37 “The Keely Motor," New York Times, 3 July 1875, 4. See also “The Keely Motor," New York Times, 11 June 1875, 1; “The Keely Motor," New York Times, 29 June 1875, 8; “The Keely Motor," Chicago Tribune, 5 July 1875, 5; "The Keely Motor," Chicago Tribune, 9 July 1875, 2; "The Steam Annihilator," Boston Globe, 14 July 1875, 4; "Keely’s Machine," Atlanta Constitution, 18 July 1875, 1.

${ }^{38}$ See, for example, “Another New Motor," Scientific American, 2 May 1874, 273; “The Keely Motor Deception," Scientific American, 11 October 1884, 230; "The Keely Motor Fraud," Scientific American, 
Why did Scientific American pursue this crusade? What work, we might ask, did the Keely Motor do for Scientific American? The simplest answer is that it sold magazines. In the late 1870s, the Keely Motor and related devices generated two or three times as many letters to Scientific American as any other topic. ${ }^{39}$ Keely also provided Scientific American with frequent opportunities for sport. Its writers had more than a little fun mocking his never-ending delays and his idiosyncratic jargon. "You see," one article imagined Keely saying, "the flibber snatcher ... acts directly on the hatchway and the slam-bang, causing them to ... start the get-up-and-get motion of the flunker-flopper, which in turn communicates its energy to the button hook and the wapperchock." When other inventors came forward with their own perpetual motion devices, Scientific American declared them, with mock indignation, to be "bare-faced infringement[s] on Keely." 40

But reading Scientific American's long campaign against the Keely Motor, one cannot escape thinking that its indignation was as much about [p. 449:] morality as science. "Any inventor who pretends to get something out of nothing ... is a deceiver," the magazine insisted in 1875, "no matter how many respectable people join hands like the Keelyites to support the deception." 41 "We cannot get something for nothing," the magazine repeated in 1885, adding emphatically, "without

28 January 1899, 59. By my count, Scientific American published 47 separate items regarding Keely and his motor between July 1875 and February 1876 alone.

${ }^{39}$ Scientific American often printed lists of "Communications Received," summarizing the topics of letters sent to the editors without printing the letters; this figure is based on my count of all letters and "Communications Received" notices published between 1874 and 1880.

40 "Keely or a Rival," Scientific American, 26 January 1878, 49; "Heat, Light, and Power Without Cost," Scientific American, 14 May 1881, 304; "Plea for a Government Perpetual Motion," Scientific American, 21 May 1881, 321; “Mr. Keely’s Motor,” Scientific American, 22 December 1888, 388.

41 “'The Keely Motor Deception,” Scientific American, 24 July 1875, 48. 
toil there is no substance." 42 Another piece compared the Keely Motor to "attempts to lift one's self over a fence by one's boot straps" — a reminder that this idiom once meant something manifestly impossible, rather than something everyone should be expected to do. ${ }^{43}$ A letter to Scientific American debunking a different perpetual motion machine opined: "In this remunerative world, we must pay, in some way, not only for corn and potatoes, but for all the enjoyment we receive, and all the power we able to exert, moral or material: Something for everything, nothing for nothing." ${ }^{44}$ This was the steady theme running through all of Scientific American's coverage of Keely and of every perpetual motion scheme from the 1840s through the 1890s: you cannot produce something from nothing.

Generations of high school science teachers and popular science writers have glossed the first law of thermodynamics in essentially the same words: "you can't get something for nothing," or, "there's no such thing as a free lunch." The second law of thermodynamics has inspired even more pessimistic readings: "you can't even break even." ${ }^{45}$ These are loose and potentially misleading glosses on the deep principles of energy physics. But such paraphrases have a long history. Even the nineteenth-century scientists who first formalized the laws of thermodynamics could not resist using moral homilies and economic metaphors to explain and support their ideas. ${ }^{46}$

A famous essay by Thomas Kuhn showed that multiple investigators came to similar conclusions about the nature of heat, force, and motion in the 1830s and 40s, in different countries

42 “A Clergyman on Shavings,” Scientific American, 28 February 1885, 128.

43 “The Keely Motor Deception Again,” Scientific American, 10 June 1876, 369.

44 “Static Pressure and the Ladies," Scientific American, 13 March 1852, 203.

${ }^{45}$ See for example Peter Nicholls and David Langford, eds., The Science in Science Fiction, 86; James Gleick, The Information, 271.

${ }^{46}$ Gillispie, The Edge of Objectivity, 400; Myers, "Thermodynamics and the Rhetoric of Social Prophecy," 310-312. 
and by different routes. ${ }^{47}$ But the laws of thermodynamics as they would be handed down to us were codified and propagated by a specific group of British scientists with a specific philosophical and political world view. These men—men like William Thomson, James Clerk Maxwell, and Macquorn Rankine- had close ties to the industrialists of Scotland and Northern England, with both groups gaining credibility from this association. They stamped the science of energy with their own commitments and preoccupations. They framed their new science in a language derived from industrial-age political [p. 450:] economy, making the whole purpose of physics the maximization of "work" and the minimization of "waste." Crosbie Smith argues that for Thomson, Maxwell, and Rankine, the laws of thermodynamics fit perfectly with "a presbyterian economy of nature" in which it was mankind's duty to seize and make useful the energy locked in the world. ${ }^{48}$ In this way, a distinct moralism crept into thermodynamic discourse.

William Thomson, later Lord Kelvin, worked to publicize the second law of thermodynamics in particular. "Although mechanical energy is indestructible," he wrote in 1862, "there is a universal tendency to its dissipation." ${ }^{49}$ This became a recurring theme in Thomson's writings and public lectures. As Greg Myers points out, the laws of thermodynamics could have been ordered in reverse, so that the reassuring aspects of what we call the first law might mitigate the gloomier implications of the second: entropy tends to increase, but the energy of the universe is constant and can neither be created nor destroyed..$^{50}$ Thomson, however, always stressed the second

\footnotetext{
${ }^{47}$ Kuhn, "Energy Conservation as an Example of Simultaneous Discovery."

${ }^{48}$ Smith, The Science of Energy, 120; Wise, "Work and Waste (III)," 221-251.

${ }^{49}$ William Thomson, "On the Age of the Sun's Heat," 349; see also William Thomson, "On a Universal Tendency in Nature to the Dissipation of Mechanical Energy."

${ }^{50}$ Myers, “Thermodynamics and the Rhetoric of Social Prophecy," 311.
} 
law and the irreversibility of entropy, which he called "dissipation." The moral connotations of this term were not accidental. Thomson often connected the laws of thermodynamics to moral and theological arguments about the creation and fate of the physical universe. ${ }^{51} \mathrm{~A}$ "universal tendency to ... dissipation" fit well with Calvinist ideas of a transitory world, destined to perish and decay. Humanity's obligation, Thomson and his colleagues would say, was to toil against the tide of entropy, fighting the sin of waste. ${ }^{52}$ The second law, then, brought temporality into physics, overthrowing older visions of the universe as a perpetual motion machine, perfect and eternal, that seemed not to require human industry.

The moralism that was subtext in Thomson's and other scientists' writings became explicit in popular coverage of Keely and his motors. "We feel morally certain that the laws of nature cannot be superseded," insisted an anti-Keely article in the Boston Globe. "Can Keely show," another critic asked, "that a foot-pound of vibratory sympathy can be more easily developed ... than a foot-pound of good honest work?" 54 The Keely Motor was not just a "puerile deception," Scientific American insisted in 1875; it represented everything wrong with America's gold rush, get rich quick, something for nothing culture. The allure of perpetual motion was "the gambler's delusion," no different than dreams of striking it rich in the Black Hills or even "turning lead into gold." ${ }^{55}$ It was not simply that

\footnotetext{
${ }^{51}$ Harman, Energy, Force, and Matter, 55-58, 66-69; Crosbie Smith and M. Norton Wise, Energy and Empire, 392-393.

${ }^{52}$ Smith, The Science of Energy, 101-125, 239-240.

53 “Is the Keely Motor a Deception?” Boston Globe, 25 June 1875, 4.

${ }^{54}$ Quoted in Moore, Keely and His Discoveries, 145.

55 “Taking a Chance,” Scientific American, 24 July 1875, 48.
} 
Keely was [p. 451:] immoral because his motor was a fraud. The motor could never work, his critics insisted, because perpetual motion—getting something for nothing—was itself immoral. ${ }^{56}$

Nineteenth-century ideas about industry and the economy were of course bound up in a Protestant ethic of virtue, merit, and hard work. Scientific American had particular reason to preach this gospel. From the 1840s through the 1890s, the magazine was owned and published by Orson Desaix Munn and Alfred Ely Beach, who also operated the patent law firm Munn and Company. Munn \& Co. was the largest patent agency in the United States, representing approximately one third of all patents issued by the U.S. Patent Office in those years ${ }^{57}$ Keely's success was an insult to the American patent system and to the idea, axiomatic at Scientific American, that the market would reward useful innovation while discarding follies and fakes. So Scientific American railed against Keely for decades, never admitting the extent to which he served them as a foil, or to which their publicity helped to power his machine.

\section{The Motor and Clara Moore}

Keely's machines did not work forever. By the early 1880s, Keely's demonstrations were attracting few attendants and fewer new investors; the motor's novelty had apparently sputtered out. ${ }^{58}$ Shares in the Keely Motor Company dropped from their peak price of $\$ 300$ per share to a mere $\$ 18$, and then to $\$ 7$. In January 1881 , the company's shareholders voted to stop paying Keely’s

\footnotetext{
${ }^{56}$ This line of argument maps closely onto what Jackson Lears has portrayed as a dialectic between America's "culture of chance" and its "culture of control." Jackson Lears, Something for Nothing.

${ }^{57}$ Frank Mott, A History of American Magazines, 2: 316-324; B. Zorina Kahn, The Democratization of Invention, 38.

58 “The Secret Out,” New York Times, 3 June 1881, 4.
} 
salary or expenses. ${ }^{59}$ When Keely threatened in retaliation to stop working on the motor and keep his secrets to himself, the company sued him. But Keely had nothing to give. By the winter of 1882, he was nearly penniless and contemplating suicide. ${ }^{60}<$ Fig. 4 (Older Keely and Motor) about here $>$

Then Keely met his savior. Clara Jessup Bloomfield Moore was the widow of paper manufacturer Bloomfield Moore, and quite possibly the wealthiest woman in Philadelphia, with a fortune of over five million dollars. ${ }^{61}$ Clara Moore had followed the Keely story, and after reading that he was on the verge of starvation, came to see his motor in action. Keely had actually disassembled the most recent incarnation of his motor, either in anguish or [p. 452:] to sell as scrap iron. But when he described his work to Moore, she said to him, "You have opened the door into the spirit world." Up to this point, Keely had resisted attempts to link his motor to any kind of occult or paranormal phenomena. He scoffed at spiritualism and insisted his work was purely mechanical in nature. But when the millionaire widow told him he had opened a door to the spirit realm, Keely was willing to reconsider. "Do you think so?” he replied. "I have sometimes thought I might be able to discover the origin of life." ${ }^{62}$

Since the moment Moore became a believer in the Keely Motor, she has been seen as his victim: a dotty rich widow bilked by a fast-talking charlatan. "He has quite turned the poor lady's

59 “The Keely Motor Deception,” Scientific American, 29 January 1881, 69.

60 “Keely's Rivals,” Boston Globe, 18 December 1882, 2; “Keely's Tantalizing Motor," New York Times, 5 July 1883, 1; Moore, Keely and His Discoveries, 105.

${ }^{61}$ "Mrs. Bloomfield Moore is Dead," Philadelphia Evening Telegraph, 5 January 1899, 2. Some sources estimate Bloomfield Moore's estate at the time of his death as $\$ 7$ million, others at $\$ 5.5$ million; even $\$ 5$ million in 1878 would be worth more than $\$ 130$ million today.

${ }^{62}$ Moore, Keely and His Discoveries, 81; on Keely and spiritualism see Paijmans, Free Energy Pioneer, 19. 
brain," said the New York Times in 1886. "She talked nothing so zealously as vibratory force," reported the Chicago Tribune, "and whatever subject she began on she was pretty sure to bring up on molecules finally." ${ }^{\prime 4}$ It is true that Moore believed in Keely's motor and would support him financially for nearly twenty years. But that is far from the whole story. In the long term, Moore would become as much the author of the Keely phenomenon as Charles Collier or Keely himself. She recast the Keely Motor and its meaning, [p. 453:] making it far more cosmic in its implications, and more direct in its challenge to the laws of thermodynamics. <Fig. 5 (Clara Moore) about here>

Clara Moore was a remarkable woman. She was a writer, the author of a dozen books including natural history, fiction, poetry, and one of nineteenth-century America's best-selling etiquette guides. She was an art collector and philanthropist; she founded an orphanage and a veterans' home in Philadelphia, and gave money and art to libraries, museums, and universities. After her husband's death, Moore split her time between the United States and England, where she became a society figure, presented at the court of Queen Victoria and on close terms with such notables as the poet Robert Browning and the occultist Helena Blavatsky. She was an advocate for women's rights and especially women's education. Moore pressed the University of Pennsylvania, where she was a generous donor, to admit women as full students. And she wrote and spoke often about the importance of post-secondary education for women, especially in the sciences. ${ }^{65}$ One of Moore's greatest regrets was that she herself never received a serious scientific education. As a

63 “Lippincott's Magazine,” New York Times, 2 October 1886, 5.

64 “Keely, The Motor Man,” Chicago Tribune, 22 April 1888, 27.

${ }^{65}$ Frances E. Willard and Mary A. Livermore, A Woman of the Century, 515-516; John A. Garraty and Mark C. Carnes, eds., American National Biography, 15: 741-742. 
young woman, she had studied in New Haven, Connecticut for three years, attending lectures at Yale, but only men could enroll. So she did her best to teach herself, reading widely if [p. 454:] eclectically and corresponding with scientists, natural philosophers, and religious thinkers, both orthodox and metaphysical. ${ }^{66}$

Moore gave Keely more than just money. She took charge of his career and became his chief publicist. She wrote two books about the Keely Motor and published articles about Keely in general interest magazines like Lippincott's as well as spiritualist and theosophical journals. ${ }^{67}$ She was a better, clearer writer than he, and far better connected. She bailed Keely out of jail, bought him out of his financial obligations to the Keely Motor Company, and introduced him to social circles he could never have reached from his workshop on Twentieth Street. She lobbied John Jacob Astor IV and Nikola Tesla on his behalf. ${ }^{68}$ She gave him books to read, ranging from cutting-edge science like Heinrich Hertz' Investigations on the Propagation of Electrical Energy, to Christian natural philosophy like John Gibson MacVicar's A Sketch of a Philosophy, to wild occultism like Helena Blavatsky's Isis Unveiled. Blavatsky devoted a chapter of her magnum opus, The Secret Doctrine, to Keely and his work; from there, the Keely Motor became a fixture in theosophical writing. ${ }^{69}$

${ }^{66}$ Clara Bloomfield Moore, Social Ethics and Society Duties, 226-227; Moore, Keely and His Discoveries, 257.

${ }^{67}$ The books are Keely and His Discoveries and Social Ethics and Society Duties; articles include Clara Moore, "The Keely Motor Secret," Lippincott's 40 (August 1887), 300-309; Clara Moore, "Keely's Secrets," Theosophical Siftings 1 (July 1888), 9-36; Clara Moore, "Aerial Navigation," The Arena 10, no. 3 (1894), 386-395.

68 “Mrs. Moore on the Keely Motor,” New York Times, 9 December 1895, 8; “An Expert on Keely's Motor,” New York Herald, 19 January 1896, n.p.; Paijmans, Free Energy Pioneer, 79-100.

${ }^{69}$ Helena P. Blavatsky, The Secret Doctrine, 1: 555-566; other examples of theosophical writing on Keely include Richard Harte, "Disintegration of Stone and Other Demonstrations of the Etheric Force”; Louise A. Off, "The Astral Light.” 
After meeting Moore, Keely's writing became markedly more metaphysical and abstract. It seems likely that Moore was telling Keely how she thought the motor worked and what it meant, much more than the other way around. Moore trained Keely to speak of "his discovery" rather than "his invention"- - her idea being that he had not simply constructed a new kind of steam engine but had revealed something about the universe. ${ }^{70}$ The motor, Moore argued, was a revelation: a refutation of the laws of thermodynamics and their supposed implications for morality, spirituality, and life.

Moore was familiar with the new science, at least in its outline and jargon. She read and cited the works of J. Robert Mayer and Herman Helmholtz, German scientists who had both articulated the principle of the conservation of energy in the 1840s. But she rejected the parsimonious economy of nature that British physicists like William Thomson attached to that principle. "The physicist tells you that 'you cannot make something out of nothing;' that in the economy of nature profit and loss must balance," Moore wrote in her 1893 book, Keely and His Discoveries. "But in the prodigality of nature, this energy flows without measure and without price, from [p. 455:] the great storehouse of the Infinite Will.” To Moore, a woman who had never wanted for material things, the Keely Motor proved that nature was not stingy but generous: "The law of the harvest," she said, "is to reap more than you sow." ${ }^{, 11}$ The universe was not winding inevitably down, as Thomson would have it, but an eternal fountain of energy and life.

For all her support of the Keely Motor, Moore showed little interest in its technical details. Her books and articles said almost nothing about the motor's actual construction, and she actually discouraged Keely from trying to perfect or patent his invention. Moore felt Keely had erred by

\footnotetext{
70 “The Keely Motor Again,” Atlanta Constitution, 27 September 1884, 4.

${ }^{71}$ Moore, Keely and His Discoveries, 148; Moore, Social Ethics and Society Duties, 55. Emphasis in original.
} 
yoking himself to the "usurers and Shylocks of commerce," who clamored for a monetizable invention long before the fundamental principles of his discovery were understood. "He was in the clutches of a speculating Keely Motor Company, whose cry was 'Give us an engine!' and day and night this toiler fought his way in the underground labyrinth, thinking only of a commercial engine," she wrote. ${ }^{72}$ She even made Keely sign a contract promising not to work on developing a commercial engine or motor, but to devote all his energy to exploring the theoretical implications of his work. ${ }^{73}$

Keely had not created energy, Moore averred, but merely discovered it. Even before meeting Moore, Keely had sometimes quoted a remark by the English scientist Michael Faraday that one drop of water, if it could be "decomposed," contained as much electrical energy as "a very powerful flash of lightning." ${ }^{\prime 74}$ Moore ranked Faraday as the greatest of scientists, and said if he had only lived long enough, he would "without doubt" have been the one to discover the hidden energy Keely had unleashed. She introduced Keely to the language of molecules and atoms, declaring that he had split the "atomic triplet" in each molecule of water to release "the mighty Genie" trapped inside. "Molecular dissociation does not create energy, as men have asserted Keely has claimed," Moore wrote, "but supplies it in unlimited quantities, as the product of the latent energy accumulated in molecular aggregation." ${ }^{, 75}$ In the twentieth century, some would claim that Keely had somehow

\footnotetext{
${ }^{72}$ Moore, Keely and His Discoveries, 242, 336.

73 “Keely's Secret," Los Angeles Times, 15 June 1890, 11.

${ }^{74}$ Quoted in “Another New Motor,” Scientific American, 2 May 1874, 273.

${ }^{75}$ Moore, Keely and His Discoveries, 171, 214.
} 
anticipated the principles of atomic energy. ${ }^{76}$ But few have recognized that these were really Clara Moore's ideas and words.

In embracing scientists like Mayer and Faraday while ignoring Thomson and Maxwell, Moore was trying to accommodate aspects of nineteenth-century physics while rejecting the philosophical conclusions many industrial-age Britons and Americans drew from them. To the scientific establishment, Mayer was an outsider, more physician than physicist, who came to discover the conservation of energy through idiosyncratic means. [p. 456:] Faraday was no outsider, but he was, for both religious and scientific reasons, opposed to the new science of thermodynamics. And both Mayer and Faraday had deep religious commitments that shaped their work. ${ }^{77}$ As the historian of science Charles Coulston Gillispie put it, to the physicists of Thomson's or Maxwell's generation, the slightly older Mayer and Faraday were "always just a touch suspect," in that one could sense in their ideas "some lingering yearning to transcend a dismalness in science, to replenish the old Democritan death of the soul in things." This undoubtedly commended them both to Moore. ${ }^{78}$

\section{Moore's Sympathetic Physics}

Moore was also staking out a feminist position on nineteenth-century debates around psychology and the scientific method. Citing the historian Henry Thomas Buckle, Moore argued that men have naturally "inductive" minds, leading them to reason from specific facts, while women have "deductive" minds, leading them to reason from general principles. Because science had always

\footnotetext{
${ }^{76}$ See for example Daniel W. Hering, Foibles and Fallacies of Science, 95.

${ }^{77}$ Caneva, Robert Mayer and the Conservation of Energy; Smith, The Science of Energy, 7-10; Geoffrey Cantor, Michael Faraday, Sandemanian and Scientist.

${ }^{78}$ Gillispie, The Edge of Objectivity, 361. It is also interesting for our purposes that, as a child, Mayer tried to construct a perpetual motion machine; his failure, he maintained, informed his later insights. Caneva, Robert Mayer and the Conservation of Energy, 4.
} 
been dominated by men, Moore argued, it was unbalanced. Nineteenth-century science had become too materialist and mechanistic. It produced an abundance of facts yet lacked underlying explanations. It broke things down into parts but could not comprehend the whole. ${ }^{79}$ It was just like a man, in Moore's view, for John Keely to have unlocked the limitless life-force of the cosmos, yet have no idea what he had done or how he had done it. It took the holistic, integrative mind of a woman to truly understand the Keely Motor and its full significance for science, religion, and philosophy.

Buckle had argued in 1858 that the wives and mothers of male scientists could render "an immense, though unconscious, service to the progress of knowledge" by encouraging more feminine, which is to say deductive, thinking in their husbands and sons. ${ }^{80}$ Moore offered a more radical suggestion: training actual women to be scientists. Science would not be whole, Moore argued, until the minds of women were as carefully and seriously trained as those of men. Without better education for women, she said, physics would remain mired in materialism, medicine would be mere quackery, and "the repulsive principles and experiences which are [p. 457:] everywhere shaking our social fabric" would never "yield to enlightened sentiment and progressive culture." 81 Moore's support for women's education brought her into direct conflict with an influential anti-feminist interpretation of the new science. In both the United States and Britain, the second law of thermodynamics was taken up with particular vigor by those who opposed higher education for women. From a twenty-first century vantage point, it is not at all clear why the laws of thermodynamics should have anti-feminist implications. But nineteenth-century medical men,

\footnotetext{
${ }^{79}$ Moore, Keely and His Discoveries, 209-215; Moore, Social Ethics and Society Duties, 221-270.

${ }^{80}$ Henry Thomas Buckle, “The Influence of Women on the Progress of Knowledge," 7.

${ }^{81}$ Moore, Social Ethics and Society Duties, 186, 228, 244.
} 
especially in the fledgling field of psychology, were eager to borrow the language and authority of the new physics. Leading neurologists like England's James Crichton-Browne and America's George Miller Beard adopted a steam-age vocabulary of "force," "pressure," and "dissipation" to talk about the nervous system and the brain. And they claimed the principles of thermodynamics as warrants for dire warnings against the education and even the mental activity of women. Women possessed less "nerve-force" than men, Crichton-Browne claimed, and what energy they did have needed to be conserved for reproduction. Nervous energy was like heat energy in a closed system, the analogy seemed to argue. ${ }^{82}$ This energy could not be created or destroyed, but it could, if misused, be dissipated into neurasthenia, hysteria, and madness.

Clara Moore's opposition to this line of argument was not just political but deeply personal. Moore's mother had been, by Clara's account, abusive and mentally unsound. ${ }^{83}$ Moore herself was prone to depression and had been hospitalized for neurasthenia, an ill-defined diagnosis popularized by Beard and others in the 1860s. And in 1879, Moore's daughter Lillian suffered a mental breakdown after the birth of her third child. Lillian's husband, a Swedish nobleman, had her committed to a Viennese hospital for the insane. Moore had a horror of asylums and no faith in the male medical profession. "The great sorrows of my life have come upon me through the ignorance of medical men," she wrote. ${ }^{84}$ She was certain Lillian would be better off in her care than locked in a "madhouse," in "confinement with the noisy insane." For the next ten years, Moore fought desperately for custody of her daughter. "The victim being a foreign subject," she wrote (putting

${ }^{82}$ George M. Beard, American Nervousness, vi, 207, 212, 336-337; James Crichton-Browne, “An Oration on Sex in Education," 1011-12.

${ }^{83}$ Moore, Social Ethics and Society Duties, 227.

${ }^{84}$ Moore, Keely and His Discoveries, 249. 
herself in the third person), "the mother is powerless, and must endure the torture of the knowledge that the last chances of her child's restoration to reason are passing away, never to return.” ${ }^{85}$

The years Moore fought to free her daughter from the asylum were the same years in which she took up John Keely’s cause. Lillian's sanity, the [p. 458:] Keely Motor, and the laws of thermodynamics were all interconnected in Moore's mind. This was made clear in her 1892 book, Social Ethics and Society Duties. Published under the pseudonym of "Mrs. H.O. Ward," Social Ethics and Society Duties was ostensibly a sequel to Moore's best-selling etiquette guide, Sensible Etiquette of the Best Society, published in 1878. But it was also Moore's most sustained argument for the education of women, her clearest explanation of what the Keely Motor meant to her, and, despite the pseudonym, a revealing, personal cry of pain.

In the book's opening pages, Moore quoted James Crichton-Browne on "the human economy," his perhaps telling term for the ties between education and mental health. This was an interesting choice, for while the quote Moore used did not make it clear, Crichton-Browne's theme was the danger of education, in particular the education of girls and women. An eminent alienist, named the Lord Chancellor's Visitor in Lunacy in 1875, Crichton-Browne was one of the loudest voices in the "over pressure" debates of the 1880s. He and other male physicians argued that too much schooling of young girls—what Crichton-Browne called "brain forcing" — was creating an epidemic of nervous disorders, suicides, and insanity. In her very next sentence, Moore quoted Robert Mayer on the essential unity of "heat, light, electricity, and magnetism," speculating that the workings of the human mind and body might also be, at bottom, nothing more than alternate "modes of motion" or "manifestations of force."

\footnotetext{
${ }^{85}$ Moore, Social Ethics and Society Duties, 153, 224, 256.

${ }^{86}$ Moore, Social Ethics and Society Duties, 7-8; Shuttleworth, The Mind of the Child, 131-140.
} 
These are odd juxtapositions for the first chapter of an etiquette guide, but Social Ethics and Society Duties is an odd book. A chapter on marital relations begins with a long quote from Keely about "aetheric" vibrations. A discussion of university education for women gives way to a poignant lament about male-dominated medicine. "The woman who has endured the mental torture of having a daughter, while in the delirium of puerperal fever, removed from her devoted care and placed in a hospital for the insane, cannot fail to comprehend the need that exists for women physicians," Moore wrote. ${ }^{87}$ Here and elsewhere in the book, Moore talked about herself in an anonymous third person, but almost every anecdote in Social Ethics and Society Duties seems to be about her family and its trials: her regret at not receiving a scientific education, her son's failure to marry, and worst of all, her daughter Lillian's breakdown and decline.

Throughout the book, Moore used the language of energy physics to talk about mental health, the education of women, and maternal love. "The brain and nervous system bear ... close resemblance to a galvanic battery in constant action," she wrote. "As long as supply and demand are fairly balanced, the functions which owe their regular and correct working to the fluid are carried on with precision.” A healthy brain and nervous system, Moore argued, need not succumb to entropy or dissipation. When one [p. 459:] loves well and enjoys the love of family, friends, and God, she wrote, "the brain has a fund of power that is inexhaustible, and the intellect is kept clear." But, Moore warned, in another anecdote too specific to be hypothetical, "let a woman of high-strung nervous organization ... be deprived of a judicious mother's care," force her to entertain guests and to undertake a taxing journey too soon after childbirth, and "as surely as the setting of the sun follows its rising," her nervous energy will become "disordered," giving rise to "abnormal, and then

\footnotetext{
${ }^{87}$ Moore, Social Ethics and Society Duties, 107-108, 253.
} 
distinctly morbid, cerebration." ${ }^{88}$ Moore's metaphors were the same as her opponents-pressure and work, engines and batteries, the conservation and dissipation of force-but her arguments were different. Unwilling to cede the authority of thermodynamics to anti-feminists like CrichtonBrowne, Moore met them on their own "scientific" ground.

Crichton-Browne and others like him warned that "brain forcing" would damage the minds of girls and young women. Moore was haunted by the fear they might be right. She knew CrichtonBrowne socially, and had consulted him regarding the treatment of her daughter. (She also tried, unsuccessfully, to interest him in the Keely Motor.) In Social Ethics and Society Duties, Moore quoted Crichton-Browne repeatedly, brooding over the way young women, "previously bright and vigorous," could become melancholy or eccentric. She worried that "the brightness of genius" often masked "the phosphorescence of decay." But she insisted, as if in answer to her own fears, that education was a virtue and a strength. Knowledge and study were necessary to develop a healthy mind and body. "When women receive equal opportunities with men for education," Moore wrote, "there will be fewer shrews, fewer weak natures, and fewer nervous, morbid, hysterical wives and mothers." 89

In the closing pages of Social Ethics and Society Duties, Moore returned to the Keely Motor. "Should he live to complete it," she wrote, "Keely's system ... will show that nature works under one law in everything; that discord is disease, that harmony is health ... that nervous and brain disorders are curable." ${ }^{\prime 90}$ Nineteenth-century physics seemed to show that heat, energy, and motive power were all forms of molecular vibration. So too, Moore insisted, were human thoughts and

\footnotetext{
${ }^{88}$ Moore, Social Ethics and Society Duties, 150-151, 154, 173.

${ }^{89}$ Moore, Social Ethics and Society Duties, 164, 166, 263.

${ }^{90}$ Moore, Keely and His Discoveries, 251.
} 
sympathies. This was the essential idea behind what Moore and Keely came to call sympathetic vibratory physics. "Sympathy" and "sympathetic attraction" were old terms for forces, like magnetism and gravity, that acted at a distance in ways early modern science could not explain. Moore used Keely's motor to give this concept a new scientific gloss. For her, love and sympathy were real physical phenomena, analogous to energy or heat, transmitted from mind to mind by vibrations in the ether. "Our brains are composed of molecules [p. 460:] ... which are in perpetual vibration," she wrote. "May not the emotional force of the brain travel through the ether in the same manner as attraction and gravity?” And Keely's motor, Moore believed, was powered by the same vibrations: in other words, the motor ran on love. ${ }^{91}$

And here, of course, was Clara Moore's own motive force. She had never been much interested in powering locomotives or selling Keely Motor Stock. For her, Keely's motor was proof of a more generous, sympathetic physics. "As force is indestructible, the human soul must be indestructible," she wrote..$^{2}$ Like energy, love might dissipate but could never truly be destroyed. The interpretation of physics that Moore derived from the Keely Motor helped her to imagine a different cosmos than the one portrayed by men like William Thomson or James Crichton-Browne. Instead of a world of entropy and toil, doomed by the second law of thermodynamics to dissipation and decline, Moore described a world governed by the first law of thermodynamics alone, where energy and sympathy were eternal and all diseases and disorders could be cured.

\footnotetext{
${ }^{91}$ Moore, Social Ethics and Society Duties, 136.

${ }^{92}$ Moore, Social Ethics and Society Duties, 137.
} 


\section{Conclusion}

John Keely, still insisting he was just on the verge of perfecting his motor, took ill and died of pneumonia in November 1898. Clara Moore died in London two months later, at the age of 74. Obituaries in the New York Times and Washington Post jumped to the conclusion that Moore had "died of a broken heart." ${ }^{93}$ Moore’s heart may have been broken, but if so, it was not for Keely so much as for her daughter, and for a millennium that never came. Lillian Moore never really recovered; she died in a Swedish asylum in $1911 .{ }^{94}$ Ten days after Clara Moore's death, her son Clarence, who had never believed in the motor, purchased Keely's Philadelphia workshop and brought in workers and reporters to dismantle the entire building in search of Keely's secret. "Every bit of flooring was ripped up," reported Scientific American with some satisfaction, and "every nook and cranny explored in the floors, walls, and ceiling." The building, investigators found, was honeycombed with hidden holes and pipes for carrying the compressed air that powered Keely's fraudulent demonstrations. ${ }^{95}$ Under the floor of his workshop was a hidden room containing a large, cast-iron sphere: a tank of compressed air, the great ball of nothing which had propelled the Keely story for so long. <Fig. 6 (Cast-iron Sphere) about here>

Scientific American was jubilant, but this was really no revelation. The magazine had guessed Keely's secret as early as 1874. Keely's fame lasted as [p. 461:] long as it did not because of the ingenuity of his devices but because of his own powers of persuasion, and the conviction of his supporters. The Keely Motor ran on compressed air, but it also ran on language and promises-

93 "Died of Broken Heart," Washington Post, 6 January 1899, 1; "Mrs. Bloomfield Moore Dead," New York Times, 6 January 1899, 6.

94 “Baroness de Bildt Dead," New York Times, 6 January 1912, 13.

95 "Investigations at the Keely Laboratory," Scientific American, 4 February 1899, 72. 
Keely's charismatic babble, Charles Collier's forecasts of profits and dividends, and Clara Moore's dreams of a more sympathetic world. It was even powered by its critics- the free publicity Scientific American and others gave the motor with their moralistic attacks.

The Keely Motor has true believers to this day. A web search will turn up dozens of websites, videos, books, and lectures devoted to Keely's supposedly suppressed discoveries, wrapped in talk of "free energy," "sympathetic vibratory physics," and "physics of love." 96 As often as not, it is Clara Moore's words and ideas that Keely enthusiasts have preserved. Keely may have built the motor, but Moore laid out its meaning in a way that would resonate for decades to come. She used the motor to construct a case against the laws of thermodynamics, or to fashion her own, more optimistic, interpretation of those laws.

It is easy enough to dismiss the Keely Motor. The deceptions that took place in Keely's second-story workshop seem transparent to us now. We [p. 462:] could divide the characters in this story into dupes and charlatans, shake our head at the gullibility of an earlier century, and leave it at that. But historians of technology should know better. We understand that no machine is judged on purely functional grounds. Every technology comes wrapped in a bundle of ideas and expectations, half-articulated longings and psychological needs. Sometimes the ideas we attach to a device are so powerful that whether or not it "works" hardly matters. The Keely Motor did not break the laws of thermodynamics. How could it? But it did defy their authority and the ideas those laws had been enlisted to support. It promised something for nothing, and a universe powered by perpetual sympathy and love.

\footnotetext{
${ }^{96}$ The most extensive collection is maintained by Dale Pond's Pond Science Institute in La Junta, Colorado, and on the web at www.svpvril.com.
} 


\section{Bibliography}

Albanese, Catherine L. A Republic of Mind and Spirit: A Cultural History of American Metaphysical Religion. New Haven: Yale University Press, 2007.

Beard, George M. American Nervousness: Its Causes and Consequences. New York: G.P. Putnam’s Sons, 1881.

Blavatsky, Helena P. The Secret Doctrine: The Synthesis of Science, Religion, and Philosophy. Vol. 1. London: Theosophical Publishing Company, 1888.

Buckle, Henry Thomas. "The Influence of Women on the Progress of Knowledge." In Miscellaneous and Posthumous Works of Henry Thomas Buckle, edited by Helen Taylor, 1: 1-19. London: Longmans, Green and Company, 1872.

Burich, Keith R. "Henry Adams, The Second Law of Thermodynamics, and the Course of History." Journal of the History of Ideas 48, no. 3 (1987): 467-482.

Caneva, Kenneth L. Robert Mayer and the Conservation of Energy. Princeton: Princeton University Press, 1993.

Cantor, Geoffrey. Michael Faraday, Sandemanian and Scientist: A Study of Science and Religion in the Nineteenth Century. New York: St. Martin’s Press, 1991.

Choi, Tina Young. "Forms of Closure: The First Law of Thermodynamics and Victorian Narrative," ELH 74, no. 2 (2007): 301-322.

Colden, Cadwallader D. The Life of Robert Fulton. New York: Kirk and Mercein, 1817.

[p. 463:] Crichton-Browne, James. "Education and the Nervous System." In The Book of Health, edited by Malcolm Morris, 269-380. London: Cassell, 1883.

Crichton-Browne, James. “An Oration on Sex in Education.” The Lancet 139, no. 3584 (1892): 1011 12.

Dircks, Henry. Perpetuum Mobile; or, Search for Self-Motive Power, During the $17^{\text {th }}, 18^{\text {th }}$, and $19^{\text {th }}$ Centuries. London: E. \& F.N. Spon, 1861.

Elkana, Yehuda. The Discovery of the Conservation of Energy. Cambridge: Harvard University Press, 1974.

Fara, Patricia. Sympathetic Attractions: Magnetic Practices, Beliefs, and Symbolisms in Eighteenth-Century England. Princeton: Princeton University Press, 1996.

Garraty, John A. and Mark C. Carnes, eds. American National Biography. Vol. 15. Oxford: Oxford University Press, 1999.

Gillispie, Charles Coulton. The Edge of Objectivity: An Essay in the History of Scientific Ideas. Princeton: Princeton University Press, 1960. 
Gleick, James. The Information: A History, A Theory, A Flood. New York: Pantheon, 2011.

Gooday, Graeme. "Re-writing the 'Book of Blots': Critical Reflections on Histories of Technological 'Failure."' History and Technology 14, no. 4 (July 1998): 265-291.

Harman, Peter M. Energy, Force, and Matter: The Conceptual Development of Nineteenth-Century Physics. Cambridge: Cambridge University Press, 1982.

Hering, Daniel W. Foibles and Fallacies of Science. London: George Routledge and Sons, 1924.

Kahn, B. Zorina. The Democratization of Invention: Patents and Copyrights in American Economic Development, 1790-1920. Cambridge: Cambridge University Press, 2009.

[p. 464:] Kuhn, Thomas. "Energy Conservation as an Example of Simultaneous Discovery." In Critical Problems in the History of Science, edited by Marshall Clagett, 321-356. Madison: University of Wisconsin Press, 1962.

Lears, Jackson. Something for Nothing: Luck in America. New York: Viking, 2003.

Lipartito, Kenneth. "Picturephone and the Information Age: The Social Meaning of Failure." Technology and Culture 44, no. 1 (2003): 50-81.

[p. 465:] Milutis, Joe. Ether: The Nothing that Connects Everything. Minneapolis: University of Minnesota Press, 2006.

Moore, Clara Bloomfield [Mrs. H.O. Ward, pseud.]. Social Ethics and Society Duties. Boston: Estes and Lauriat, 1892.

Moore, Clara Bloomfield. Keely and His Discoveries. London: Kegan, Paul, Trench, Trübner \& Company, 1893.

Mott, Frank. A History of American Magazines. Vol. 2, 1850-1865. Cambridge: Harvard University Press, 1938.

Myers, Greg. "Nineteenth-century Popularizations of Thermodynamics and the Rhetoric of Social Prophecy." In Energy and Entropy: Science and Culture in Victorian Britain, edited by Patrick Brantlinger, 307-38. Bloomington: Indiana University Press, 1989.

Nicholls, Peter and David Langford, eds. The Science in Science Fiction. New York: Knopf, 1983.

Off, Louise A. “The Astral Light.” Theosophical Siftings 3, no. 7 (1890): 24.

Oppenheim, Janet. Shattered Nerves: Doctors, Patients, and Depression in Victorian England. Oxford: Oxford University Press, 1991.

Ord-Hume, Arthur W.J.G. Perpetual Motion: The History of an Obsession. London: George Allen \& Unwin, 1977. 
Paijmans, Theo. Free Energy Pioneer: John Worrell Keely. Kempton, Ill.: Adventures Unlimited Press, 2004.

Petroski, Henry. To Engineer is Human: The Role of Failure in Successful Design. New York: St. Martin's Press, 1985.

Petroski, Henry. To Forgive Design: Understanding Failure. Cambridge: Belknap Press, 2012.

Pond, Dale, ed. Universal Laws Never Before Revealed: Keely's Secrets. Santa Fe, N.M.: The Message Company, 1996.

Rankine, William John Macquorn. A Manual of the Steam Engine and Other Prime Movers. London: Richard Griffin and Company, 1859.

[p. 466:] Schaffer, Simon. "The Show That Never Ends: Perpetual Motion in the Early Eighteenth Century." British Journal for the History of Science 28, no. 2 (1995): 157-189.

Shuttleworth, Sally. The Mind of the Child: Child Development in Literature, Science, and Medicine, 18401900. Oxford: Oxford University Press, 2010.

Smith, Crosbie. The Science of Energy: A Cultural History of Energy Physics in Victorian Britain (Chicago: University of Chicago Press, 1998), 1-14.

Smith, Crosbie, and Ian Higginson. "Consuming Energies: Henry Adams and 'The Tyranny of Thermodynamics'.” Interdisciplinary Science Reviews 26, no. 2 (2001): 103-111.

Smith, Crosbie, and M. Norton Wise. Energy and Empire: A Biographical Study of Lord Kelvin. Cambridge: Cambridge University Press, 1989.

Thomson, William. "On a Universal Tendency in Nature to the Dissipation of Mechanical Energy." Philosophical Magarine 4, no. 25 (1852): 304-306.

Thomson, William. “On the Age of the Sun's Heat.” In Popular Lectures and Addresses, 1: 349-368. London: Macmillan, 1889.

Tresch, John. The Romantic Machine: Utopian Science and Technology after Napoleon. Chicago: University of Chicago Press, 2012.

Willard, Frances E., and Mary A. Livermore, eds. A Woman of the Century: Fourteen Hundred Seventy Biographical Sketches Accompanied by Portraits of Leading American Women in All Walks of Life. Buffalo, N.Y.: Charles Wells Moulton, 1893.

Wise, M. Norton. "Work and Waste: Political Economy and Natural Philosophy in Nineteenth Century Britain (I).” History of Science 27, no. 3 (1989): 263-301.

Wise, M. Norton. "Work and Waste: Political Economy and Natural Philosophy in Nineteenth Century Britain (II).” History of Science 27, no. 4 (1989): 391-449. 
Wise, M. Norton. "Work and Waste: Political Economy and Natural Philosophy in Nineteenth Century Britain (III).” History of Science 28, no. 3 (1990): 221-261.

Wood, Henry. "The Dynamics of Mind.” The Arena 11, no. 63 (1895): 302-309.

Figures and Captions

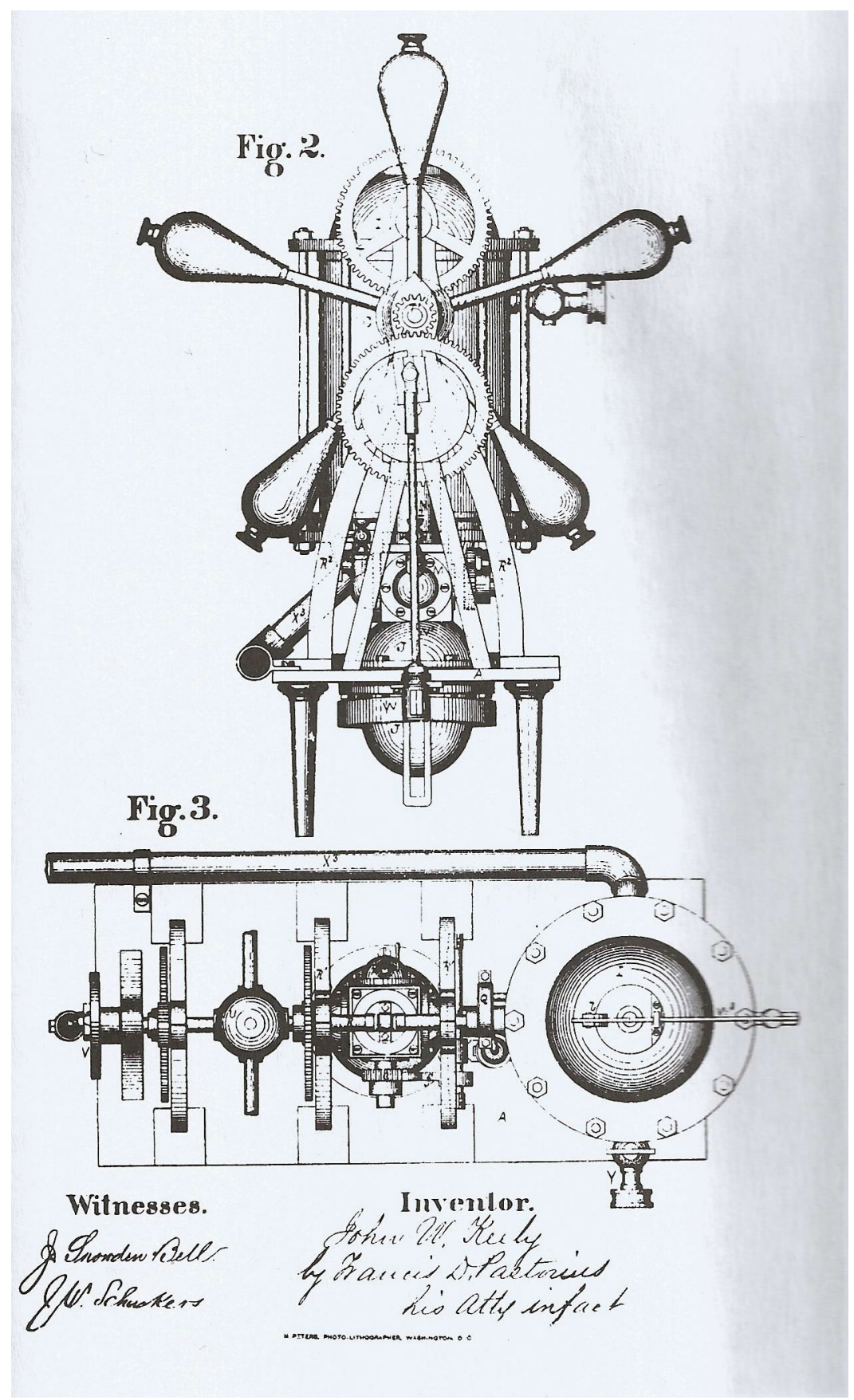


Fig. 1 Diagrams from Keely's unsuccessful application to patent a “Hydro Pneumatic Pulsating Vacuo Engine." The U.S. Patent Office had an effective response to any application that resembled perpetual motion: they asked Keely to present a working model of his device. Keely asked to be excused from this requirement, arguing "the drawings are very complete and fully illustrate the invention." The patent examiners remained unmoved. (Source: John Worrell Keely, Hydro Vacuo Engine, U.S. Patent Application, filed November 14, 1872.)

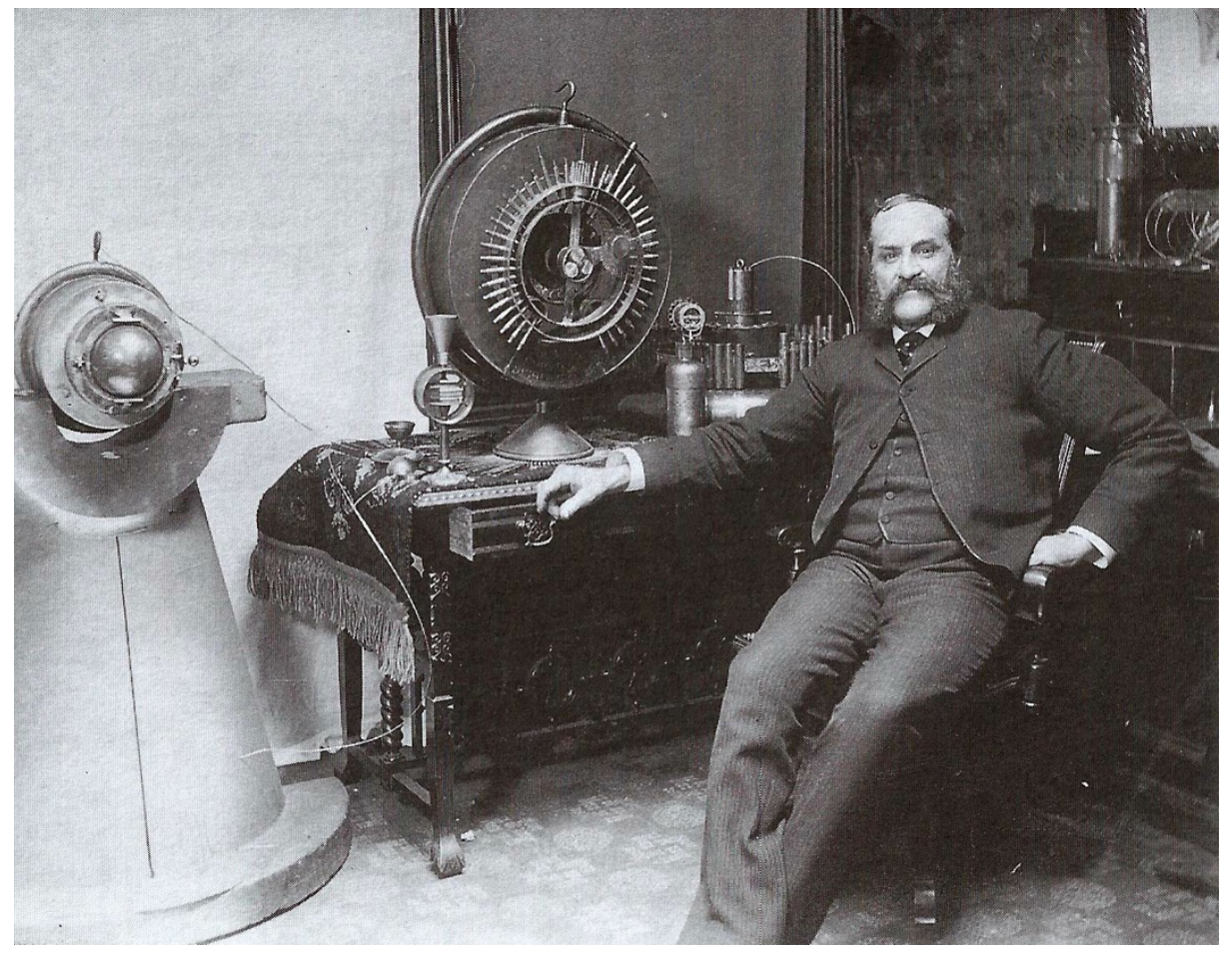

Fig. 2 John Worrell Keely and his invention. Keely's terminology was confusing, and his labels for different parts of the Motor shifted over time. This photograph of Keely in his workshop, taken in the late 1870s or 1880s, probably shows (from left) the vibratory globe (small globe on large stand), the liberator (small device on desk), and the compound disintegrator (large wheel on desk). (Source: Wikimedia Commons.) 


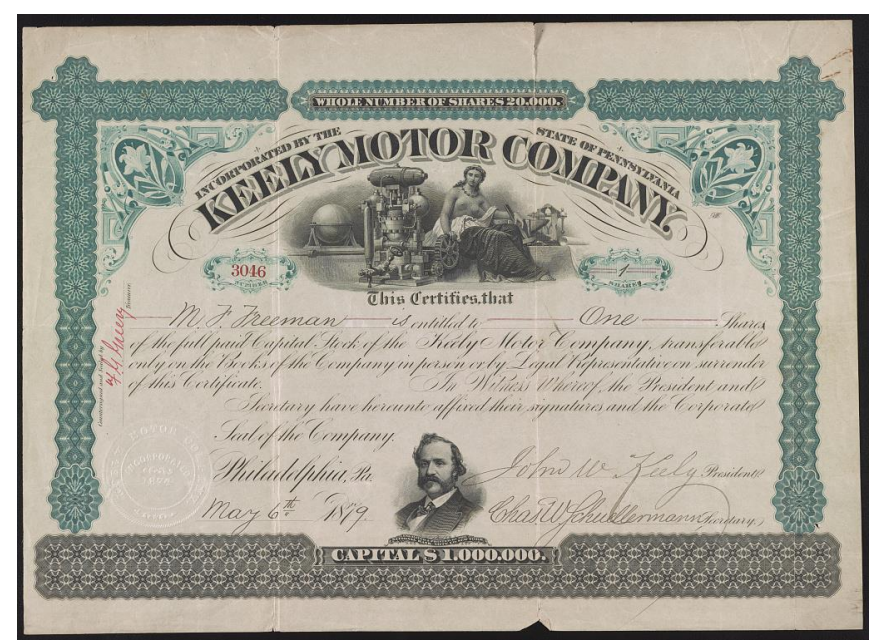

Fig. 3 Keely Motor Company stock certificate. Shares in the Keely Motor Company rose in value from $\$ 50$ per share to $\$ 150$ by 1879 . Some sold for as much as $\$ 300$. By the early 1880 s, the shares were essentially worthless, though many of Keely's investors kept the faith and continued supporting him for years. (Source: Library of Congress Prints and Photographs Division.)

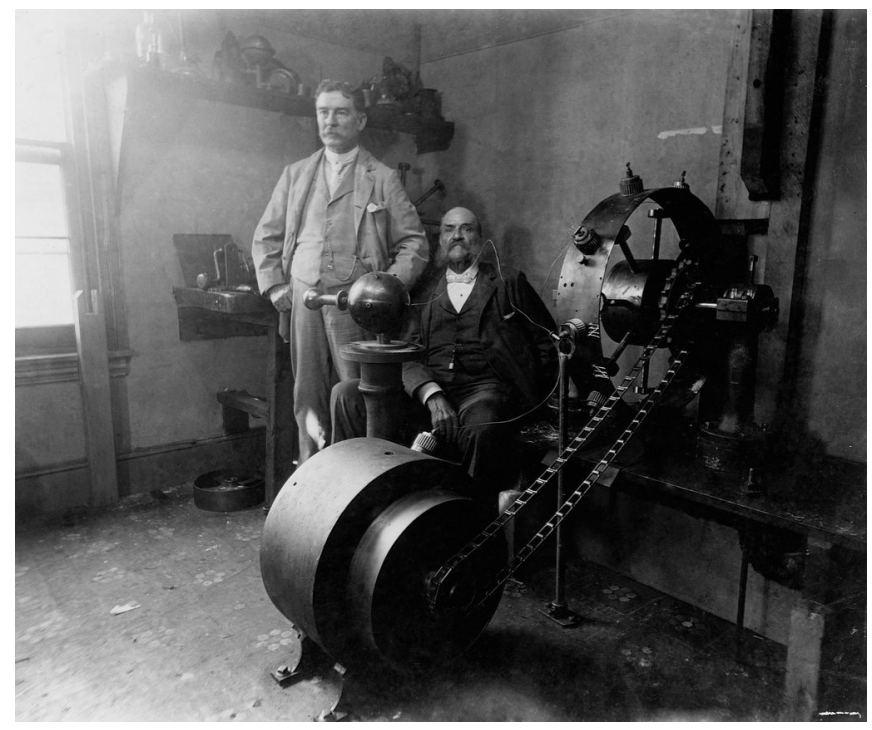

Fig. 4 An older Keely (seated) with a later, larger incarnation of the Keely Motor, and an unidentified man. (Source: Library of Congress Prints and Photographs Division.) 


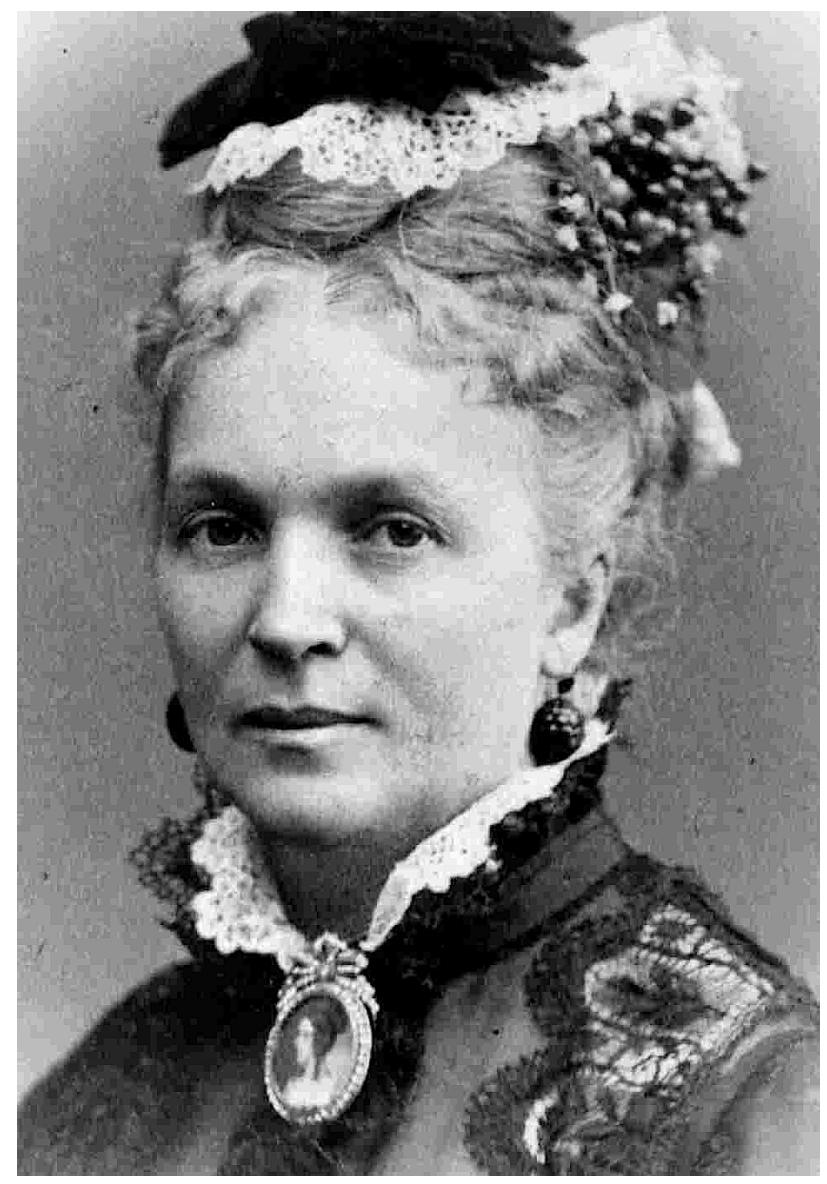

Fig. 5 Clara Jessup Bloomfield Moore, the wealthy widow of paper manufacturer Bloomfield Moore, was an author, art collector, and philanthropist. Besides supporting Keely financially for decades, she framed his motor in spiritual, philosophical, and feminist terms, and was in many ways an equal co-author of the Keely Motor phenomenon. (Source: Wikimedia Commons.) 


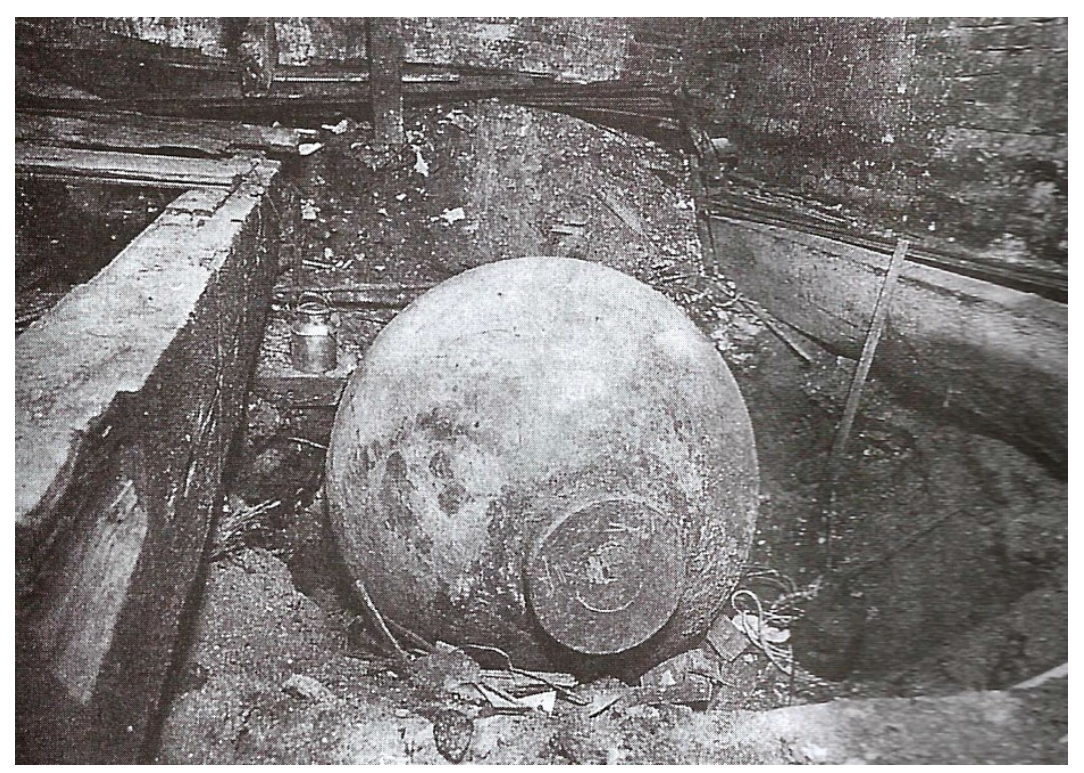

Fig. 6 After Keely and Moore died, Moore's son Clarence hired workers and investigators to dismantle Keely's workshop. They discovered a large cast-iron sphere concealed under the floor: a tank for the compressed air that Scientific American said must have powered all of Keely's inventions. (Source: "Investigations at the Keely Laboratory," Scientific American, February 4, 1899, p. 72.) 